\title{
11 \\ Community Consultations: Local Responses to Large-Scale Mining in Latin America
}

\author{
Mariana Walter and Leire Urkidi
}

\section{Introduction}

This chapter studies the emergence and spread of community consultations in large-scale metal mining projects in Latin America. These consultations are different from the free, prior and informed consent (FPIC)-related consultations, or consulta previa, that are fostered by national governments. From Tambogrande (Peru) in June 2002 to Mataquescuintla (Guatemala) in November 2012, 68 consultations/referenda have been conducted in Peru, Argentina, Guatemala, Colombia and Peru. In all cases the result has been a large opposition to mining projects. This process is occurring in a context of growing pressures to extract mineral ores in Latin America and an increasing number of related socioenvironmental conflicts (see Chapter 2). The particularity of these consultations is that these are not commissioned by national governments as part of official procedures to consult communities but instead are promoted by environmental justice movements (EJMs), usually with the support of local governments.

The emergence and spread of consultations in Latin America remains poorly studied. Studies addressing mining consultations/referenda have focused on the first four cases: Tambogrande, Esquel, Sipakapa and Majaz/Río Blanco (Muradian, Martinez-Alier and Correa, 2003; Subies et al., 2005; Haarstad and Floysand, 2007; De Echave et al., 2009; McGee, 2009; Walter and Martinez-Alier, 2010; Fulmer, 2011; Urkidi, 2011; Bebbington, 2012a); along with the wave of consultations in Guatemala (Holden and Jacobson, 2008; Rasch, 2012; Trentavizi and Cahuec, 2012). 
Nevertheless, the cases that followed, their connections and the institutional features of consultations have received poor scholarly attention. This research is born from the curiosity of understanding how and why these consultations have emerged and spread, and how community consultations are challenging the governance of mining activities.

Analysing the cases of community consultations conducted in Latin America from 2002 to 2012, we claim that these consultations (1) emerge in the context of environmental justice struggles and criminalization; (2) aim to reclaim the right of affected populations to participate, in empowering forms, in high-stakes decision-making that affect their lands and livelihoods; and (3) are a hybrid institution, the product of a dynamic multiscalar process where non-state and state actors, and formal and informal institutions, are mobilized to challenge the centralized governance of extractive activities.

\section{Struggles over the governance of mining activities in Latin America}

As mentioned in Chapter 1, there is an ongoing shift in views that frame resource regulation from those that are led by state-based institutions of resource management (government) to a wider environmental governance perspective. The governance approach addresses the myriad of actors and institutions that guide the ways in which (global) environmental issues are addressed across different scales (Bulkeley, 2005).

State-centred frames are increasingly unsatisfactory and anachronistic to understanding different ways in which regulation is constructed and reconstructed. Recognizing the different spatial grammars at play becomes necessary in order to understand the emergence of hybrid forms of environmental governance and their implications (Bulkeley, 2005). Hybrid forms of governance challenge the conventionally recognized social roles of markets, states and, more recently, communities, as new dynamics and alliances are formed. Hybrid governance entails the formation of complex political spaces: networks of social, economic and cultural relations, actors connecting from distant locations, sharing networks with common social and political objectives.

In this chapter we refer to hybrid governance as a process of institutional bricolage where different (non-state and state) actors shape institutions that combine formal and informal components in a multiscalar dynamic. We conceive scale as an epistemological, not an ontological, entity. Leitner, Seppard and Sziarto (2008: 159) conceptualize scale 
"as a relational, power-laden and contested construction that actors strategically engage with, in order to legitimize or challenge existing power relations".

Hybrid institutions can be addressed from different theoretical perspectives. Instrumentalist approaches assume that actors are political and social entrepreneurs who actively use their social capital to build institutions that strive for optimal resource management. It is usually claimed that, to use social capital appropriately, institutions must be properly embedded in the cultural and social context from which the norms to support purposive decision-making are drawn (Ostrom, 1990). However, it has been claimed that concepts of embeddedness foster a functional and static conceptualization of culture and tradition that obscures the complex dynamics of institutional construction and evolution (Cleaver, 2001). Cleaver (2002: 17) claims that "the evolution of collective decision-making institutions may not be the process of conscious selection of mechanisms fit for the collective action task (as in Ostrom's model) but rather a messier process of piecing together shaped by individuals acting within the bounds of circumstantial constraint".

In her studies of institutions for common property resource management in Tanzania, Cleaver $(2001,2002,2013)$ develops the concept of "institutional bricolage" as a process by which people consciously and unconsciously draw on existing social and cultural arrangements (rules, traditions, norms, roles and relationships) to shape institutions in patch-together institutions to change situations (Cleaver et al., 2013). In this dynamic, the resulting institution is a mix of modern and traditional, of formal and informal practices. Institutional bricolage offers a compelling approach to understanding the way in which hybrid institutions can be the result of a complex and dynamic assemblage process where contexts, conflicts, needs, scales, actors, and formal and informal institutions come into play to produce a particular hybrid institution.

\section{Environmental Justice Movements (EJMs)}

Latin American anti-mining movements and organizations played a central role in the emergence and spread of consultations. In this section we outline some key features of this actor, its central demands and its scalar dynamics.

Latin American anti-mining movements have been framed as EJMs because they demand socioecological equity and fair decision-making processes in the governance of mining activities (Urkidi and Walter, 2011). Recently, questions of participation and voice have been at 
the forefront of environmental justice studies (Schlosberg, 2007). The concept of environmental justice was born in the 1980s in tandem with Afro-American social movements fighting environmental racism (Bullard, 1990). Since then, the concept has travelled among social movements and has been appropriated by other social groups and movements in the world. As a result, national and regional environmental justice networks have emerged in Latin America in recent decades (Carruthers, 2008). Mining concerns and anti-mining movements have a central place in these Latin American networks.

It has been pointed out that the concept of environmental justice entails a politics of scale because it refers to the spatial and social distribution of environmental impacts and economic benefits, and to the scales, institutions and agents that regulate environmental decisions (Kurtz, 2003). Some political geographers express criticism regarding EJMs' "militant particularism" (Harvey, 1996), according to which movements have to find a way to cross the problematic divide between actions that are profoundly embedded in place and local experience, on the one hand, and a wider movement and discourse on the other. According to this perspective, local loyalties and identity politics of resistance movements prevent engagement in wider and emancipating politics of scale. We claim, however, that EJMs tend to transcend placebased militant particularism (Kurtz, 2003). EJMs build strategies and discourses that transcend the particularities of local demands, acknowledging the structural roots of their struggles and establishing solidarity networks with other communities and groups (Urkidi and Walter, 2011). These networks have been key for anti-mining groups in Latin America, such as OCMAL and the No a la Mina platform in Argentina.

EJMs should not be seen as static but rather as learning and flexible movements that expand and contract in space as conflicts unfold and movements jump scales (Smith, 1996; Leitner, Seppard and Sziarto, 2008). There are different spatialities at play in contentious politics (e.g. scale, networks, place, mobility), and participants usually draw on several at once (Leitner, Seppard and Sziarto, 2008). The analysis of EJMs should also acknowledge this spatial complexity. We claim that these features of EJMs played a central role in the shaping of community consultations.

EJM concerns usually address three key dimensions of environmental justice: distribution, recognition and participation (Schlosberg, 2007). These can be seen as key lenses through which EJMs frame injustice. EJMs address not only inequity but also, and sometimes centrally, the 
political processes that construct environmental inequities. Anti-mining groups in Latin America frequently argue that the approval of mining projects involves the misrecognition of the material and cultural dependence on water and land of the affected populations and that it ignores the concerns expressed in local participatory stages, or that it lacks such spaces altogether (Muradian, Martinez-Alier and Correa, 2003; Haarstad and Floysand, 2007; Urkidi and Walter, 2011).

The main features of the procedures that govern mining activities are shared by most Latin American countries. Indeed, Latin American mining laws were developed under similar guidelines drafted by international financial institutions (e.g. the World Bank) (Chaparro, 2002; Bridge, 2004). The approval of mining projects is centralized in the national (or provincial, in the case of Argentina) government, and is based on the assessment of an environmental impact report. Participation arenas are set in relation to this technical document and are non-binding. Civil society actors can usually present allegations (e.g. online or on paper) and, sometimes, can express their views in front of a public audience where the technical document is presented. Usually, law requires that these concerns be addressed by the mining company when providing the final environmental impact assessment that has to be approved by the national government (usually by the mining or environmental departments). However, EJMs claim that participation in mining decisions is mainly "informative" and insufficient, when not secretive (Janhcke Benavente and Meza, 2010).

Projects affecting indigenous communities are under specific regulations. Most Latin American countries (all those studied in this chapter) have subscribed to the 169 ILO Convention, which requires the prior and informed consent of communities before decisions about activities that could affect them are made, a process that should follow customary procedures. This right is usually ignored or misapplied (Janhcke Benavente and Meza, 2010). However, even if put in practice, the way the 169 ILO Convention and other international documents (e.g. the UN Declaration on the Rights of Indigenous People) frame "consent" is ambiguous and does not necessarily imply a binding power to community views (McGee, 2009; Janhcke Benavente and Meza, 2010). As the cases presented in this chapter illustrate, and as pointed out by other studies (e.g. Janhcke Benavente and Meza, 2010), the way decisions regarding mining activities exclude or mistreat local actors, their values, concerns and institutions is fuelling unrest and frustration among the affected communities. 


\section{The rise and spread of mining consultations in Latin America}

In order to study the process of emergence and spread of Latin American mining consultations, we identified and analysed all cases of metal-mining consultations/referenda fostered by EJMs from 2002 (Tambogrande) to 2012 in Latin America. We considered those consultations/referenda that were not fostered by the central government or private companies as part of an official consultation process, and aimed to consult the local citizens at large whether or not a community/municipality/district was in favour of large-scale metal mining activities in their territory.

We reviewed and triangulated primary and secondary, and activist and academic, sources (e.g. newspapers, activist and government websites, reports, scientific papers). As the analysis unfolded, we identified the main commonalities and differences, and developed a series of hypotheses for the emergence and spread of consultations that made us revisit and expand our sources: an iterative process that led us to refine the findings outlined in this chapter.

We identified 68 metal-mining consultations in five Latin American countries: Peru (2002, 2007, 2008, 2009, 2012), Argentina (2003, 2012), Ecuador (2011), Colombia (2009) and Guatemala (57 municipal consultations from Sipakapa in 2005 to Mataquescuintla in 2012) (Tables 11.1 and 11.2). We grouped the cases into three main "travel paths" according to the connections and similarities of consultation cases, not their chronological order. In this vein we aim to identify how consultations have been transmitted from conflict to conflict as a useful participation institution. For each "travel path" we highlight the key elements of the leading case(s), identify how consultations emerged, their institutional features and the EJMs involved, and analyse the multiple spatialities at play in the transference of consultation experiences among EJMs.

The first travel path presents the main features of the first consultation case in Tambogrande (2002), the spread of the experience to other Peruvian communities and its arrival in Ecuador. The second travel path outlines the key features of the Argentinean process triggered by Esquel (2003). The third travel path addresses the Guatemalan wave of consultations born from Sipakapa (2005), and the arrival of this experience in Colombia. The case of Guatemala presents some particular features. While the first case of consultation (Sipakapa) occurred in the context of an active conflict, most of the following cases were part of a regional campaign to prevent the expansion of mining activities in the country. 


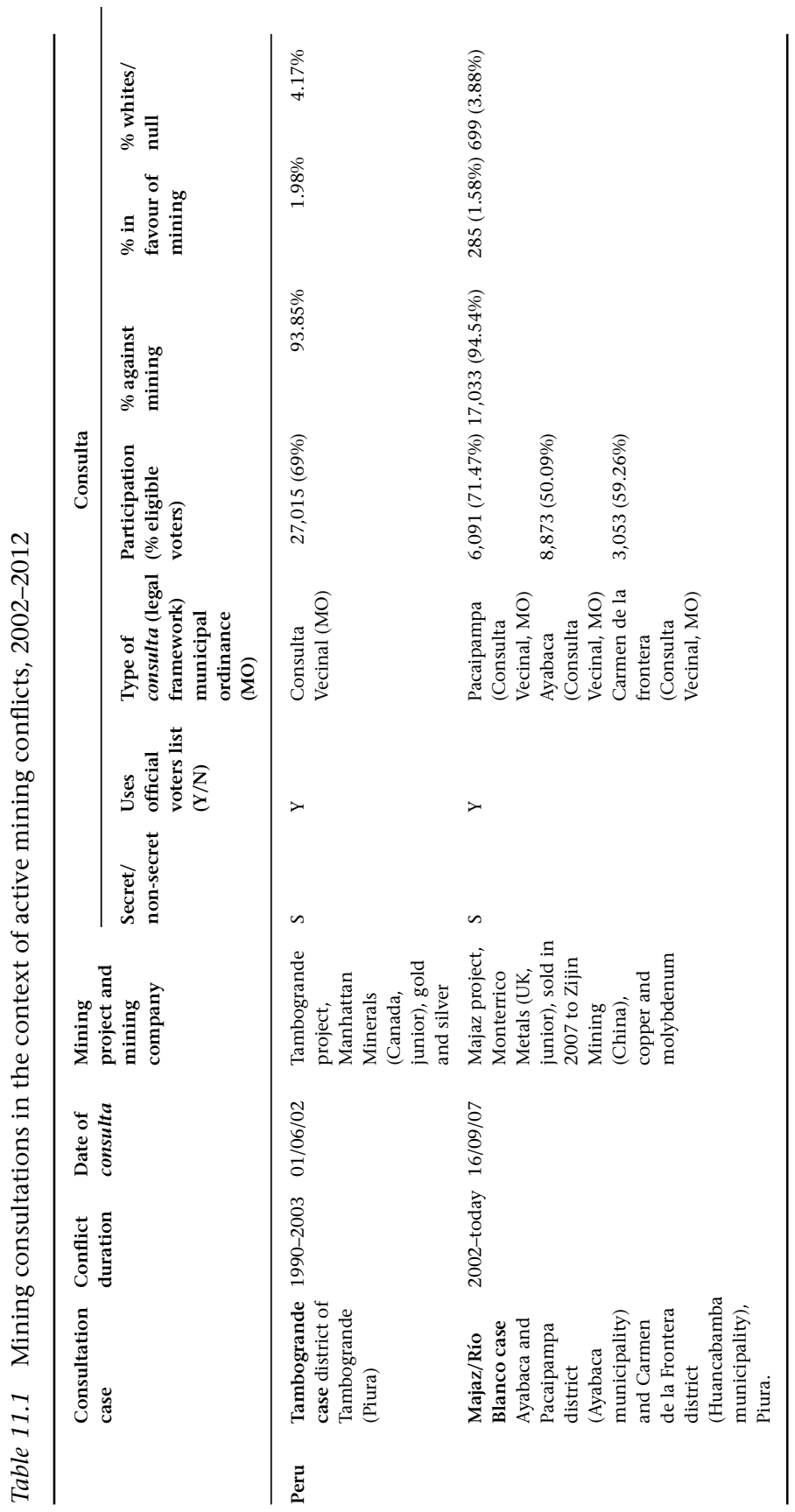




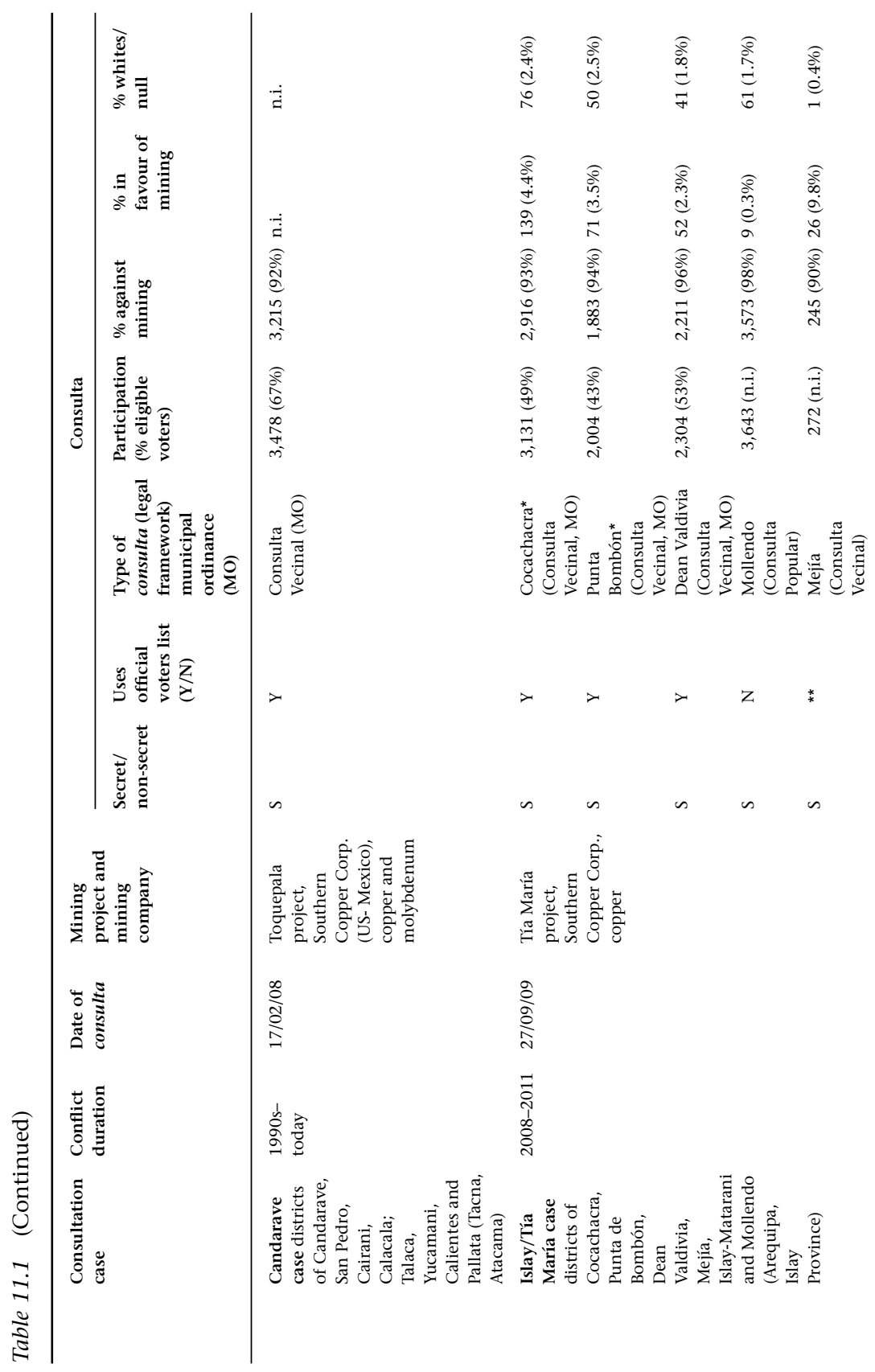




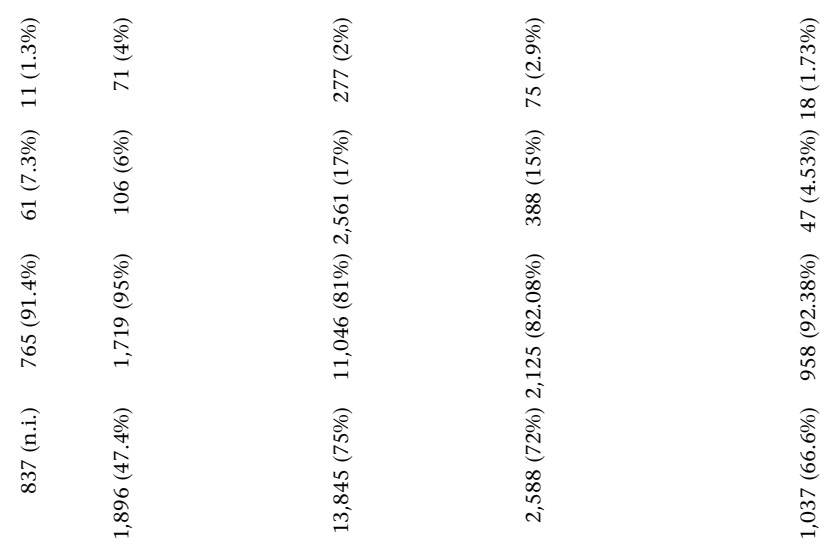

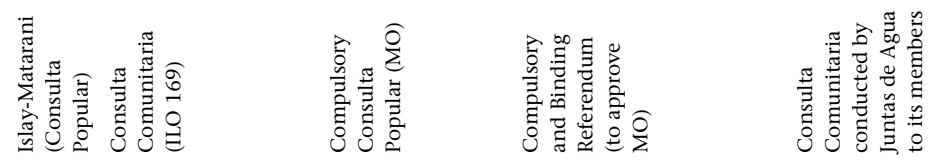

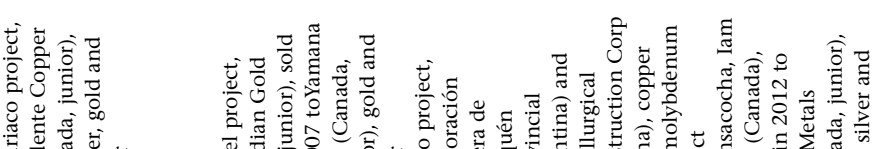

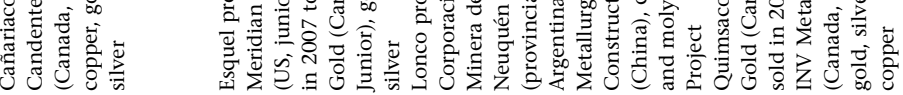

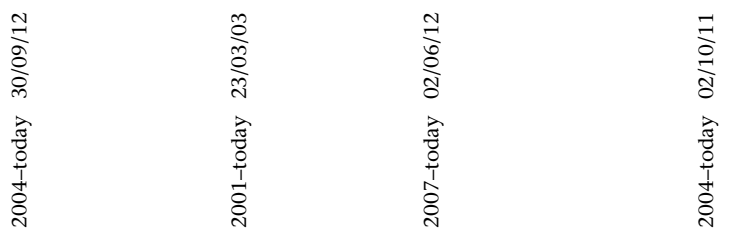

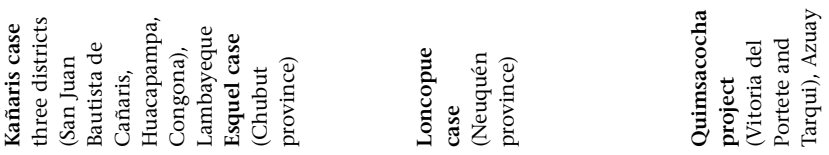
莺 


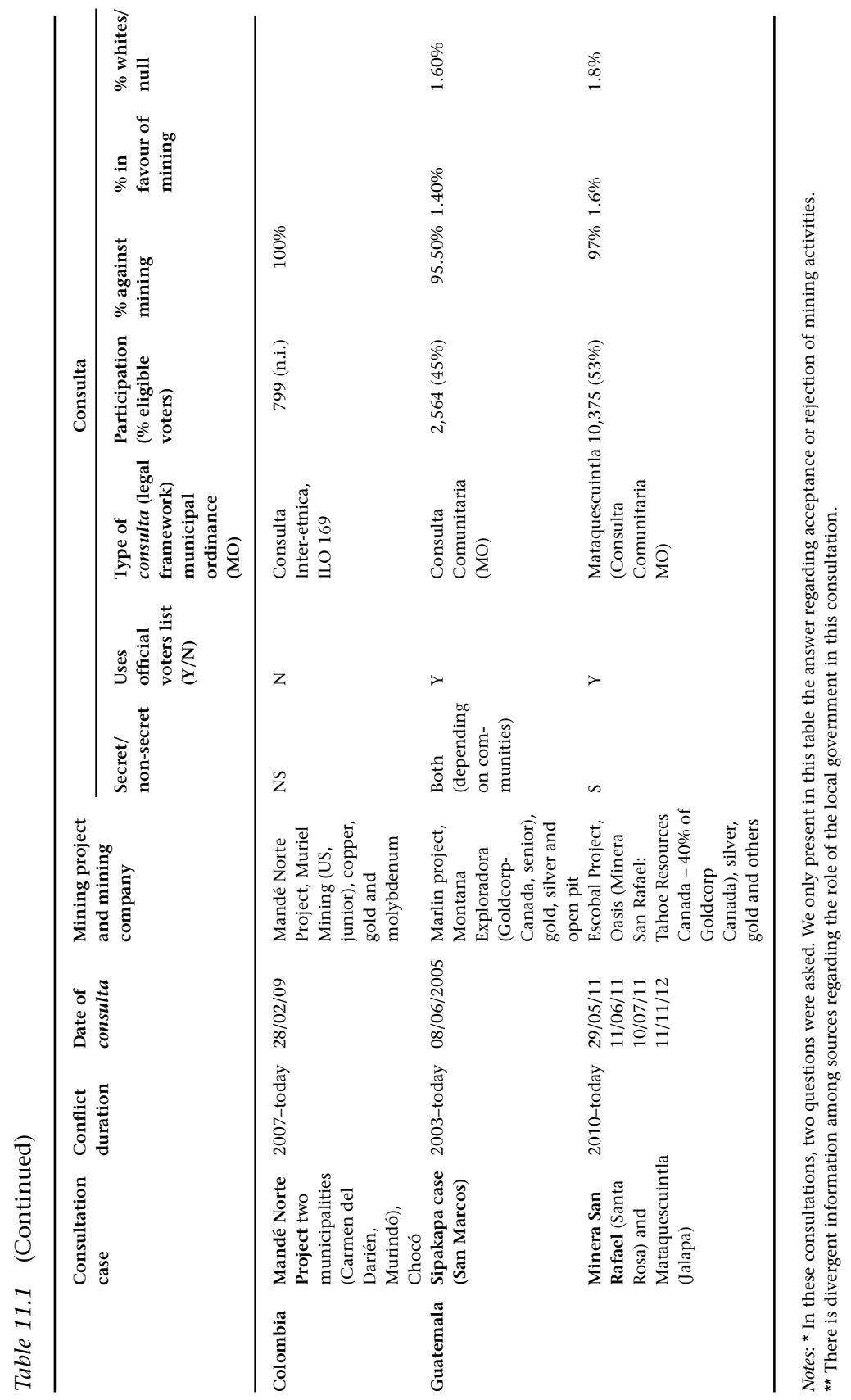




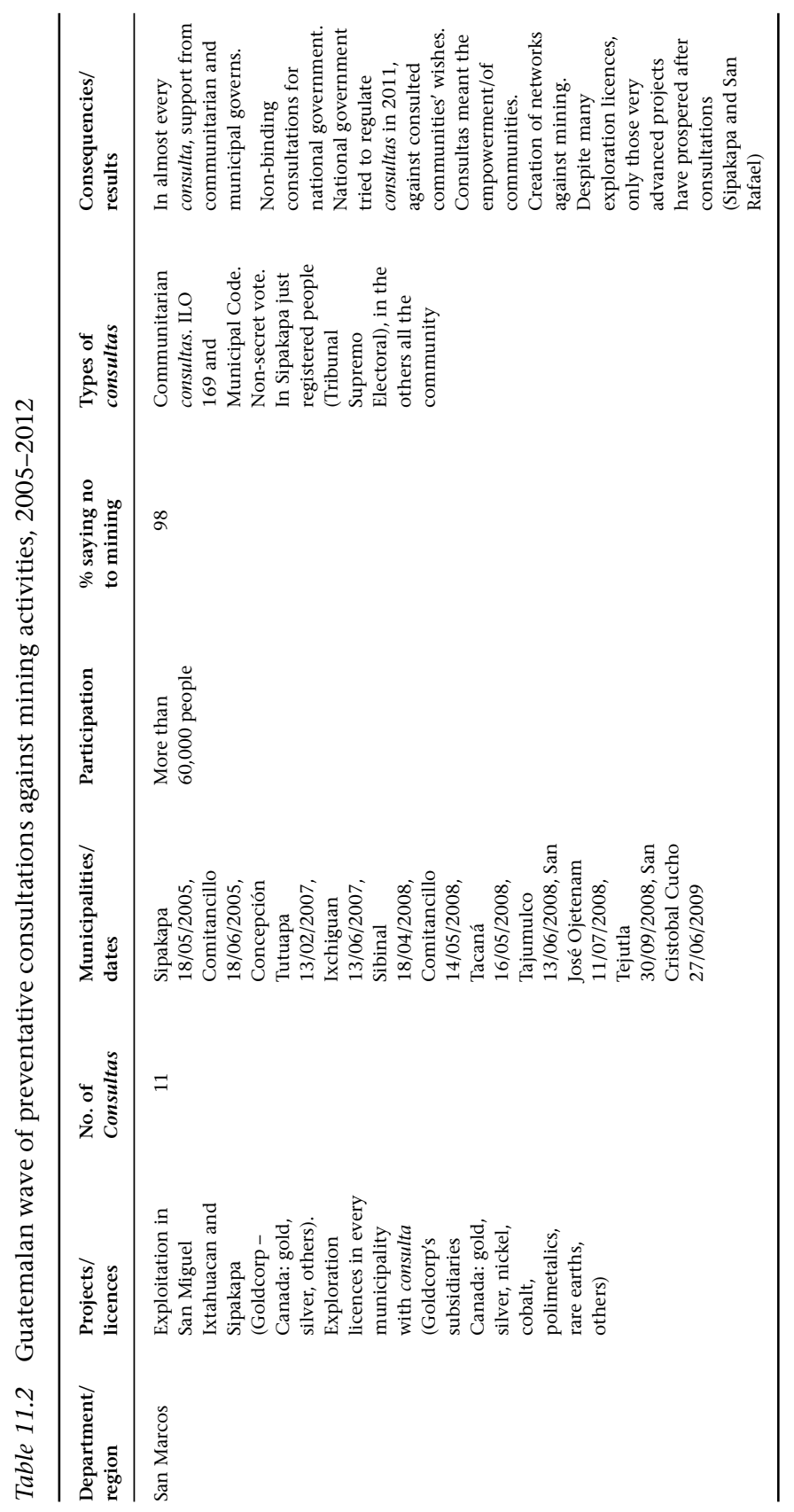




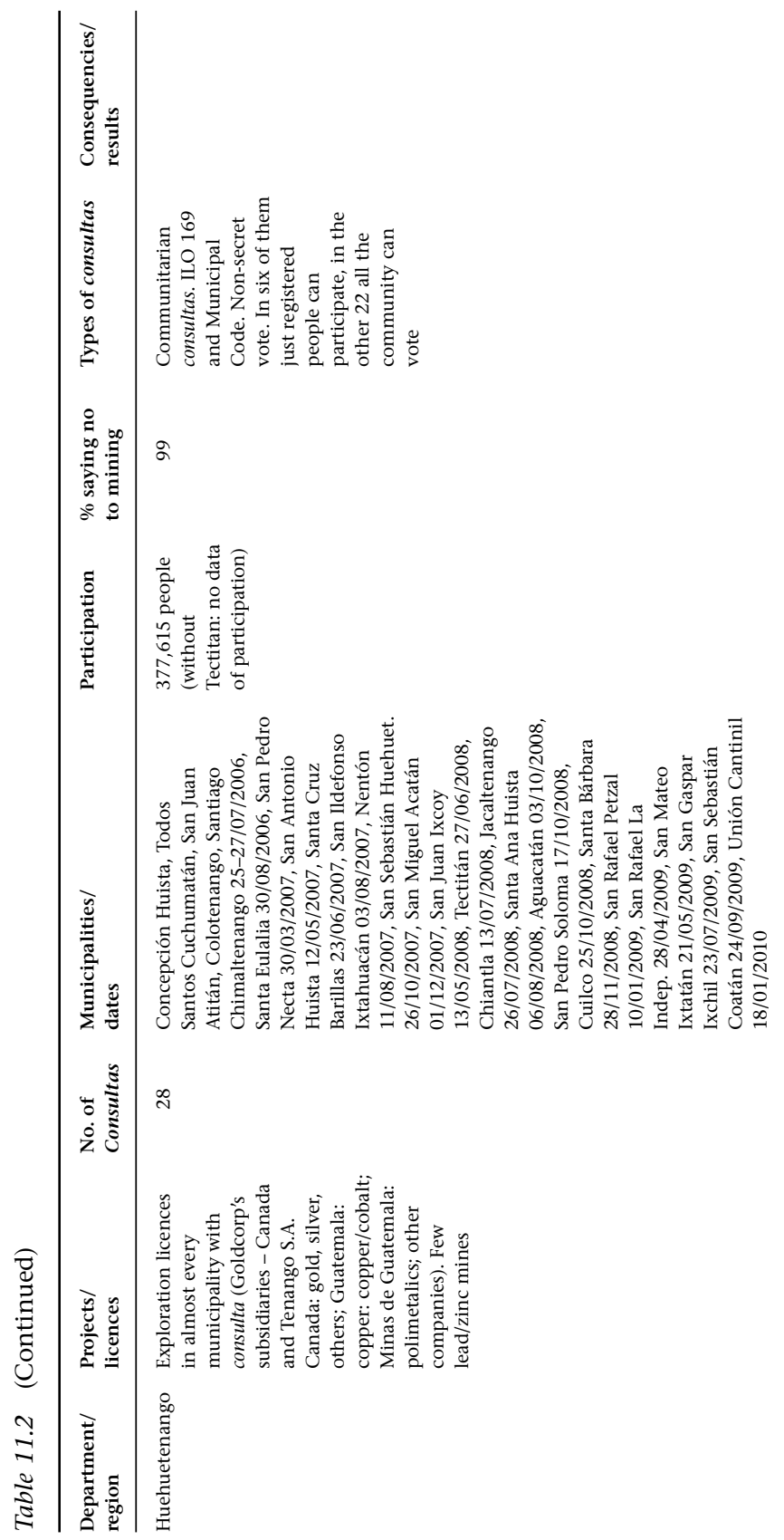



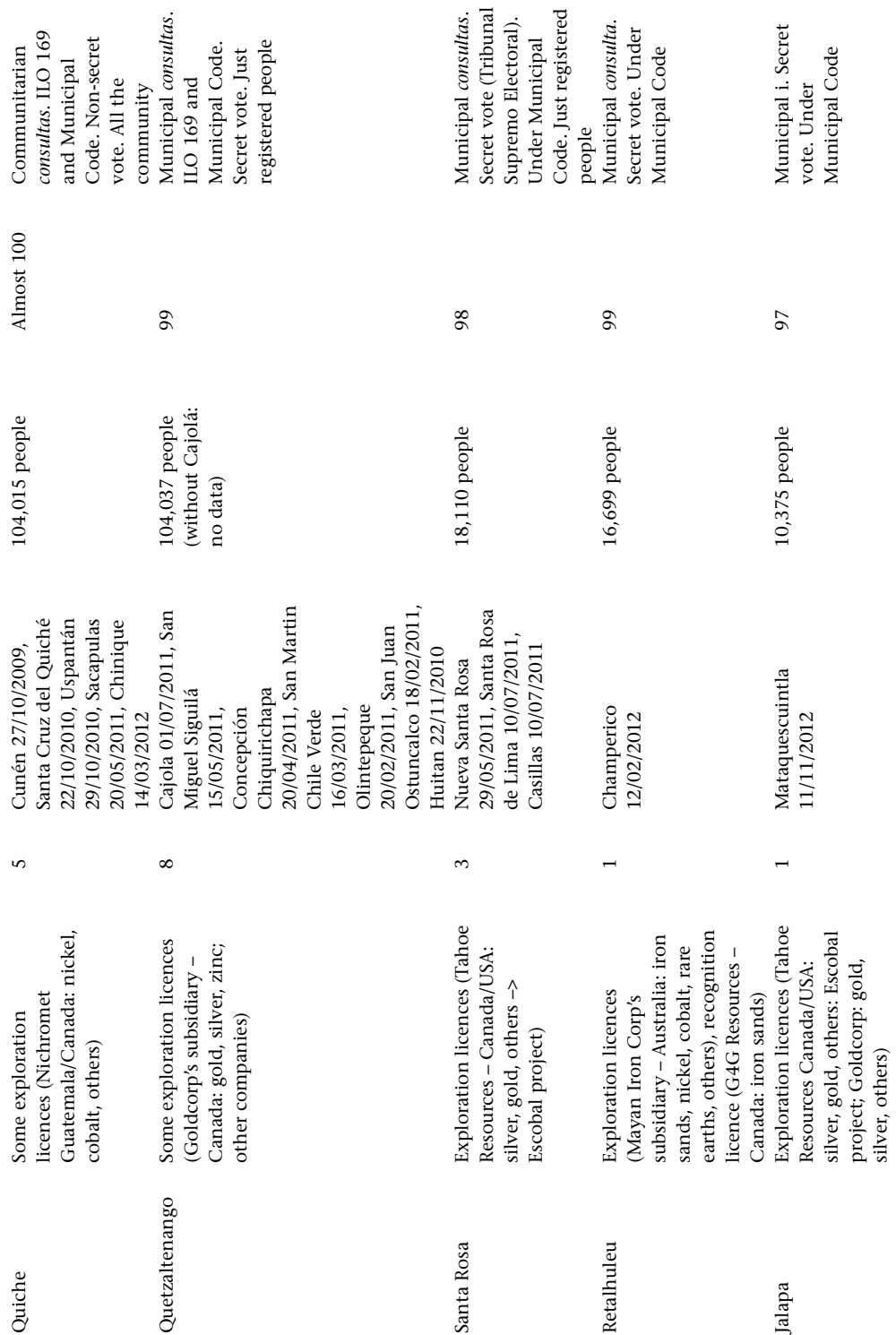

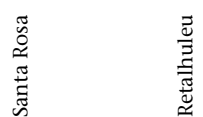

莺 
We explain the Sipakapa consultation in more detail and refer to the following cases as a regional process.

\section{Emergence and spread in Peru and Ecuador}

Tambogrande conflict (Piura)

Tambogrande is located in one of the poorest departments of Peru (Piura), with an arid climate that requires dams and irrigation canals (built with World Bank support) to sustain its agricultural exportoriented activities. The conflict was triggered by the Manhattan Minerals project, whose main deposit was located under the town of Tambogrande. Critical voices pointing to the environmental and social impacts of this activity, led by a local farmer and agrarian engineer who had emigrated from Lima, fostered the formation of the Frente de Defensa de Tambogrande y el Valle de San Lorenzo in 1999. This organization became the main local opposition to the project in collaboration with the local church and the National Coordinating Confederation of Communities Affected by Mining (CONACAMI) (Portugal Mendoza, 2005).

As the Frente was unable to engage in an exchange of views and concerns with the national government, local unrest rose (Portugal Mendoza, 2005). In March 2001, after a period of strikes, massive mobilizations and violent events in Tambogrande, the local leader Godofredo García Baca was shot dead by a hooded gunman (Muradian, Martinez-Alier and Correa, 2003). These events made the mining conflict nationally and internationally known (The Economist, 23 June 2001), thereby engaging new national and international support. Professionals from Piura and Lima constituted a working group to elaborate technical arguments and reports against the project, succeeding in involving transnational organizations and networks in the local struggle (Bebbington, Humphreys Bebbington and Bury, 2011).

Local tension was growing and social movements became concerned with a possible escalation of violence (Portugal Mendoza, 2005; Cabellos and Boyd, 2007; McGee, 2008). In this context, the Frente, its allies and Tambogrande's mayor - who was not clearly positioned before - agreed on the need to conduct a consulta vecinal (neighbours' consultation), a peaceful and democratic mechanism to channel local unrest and express local views (Portugal Mendoza, 2005; Subies et al., 2005; Bebbington, Humphreys Bebbington and Bury, 2011).

The municipality of Tambogrande issued the Municipal Ordinance No. 012-2001-MDT-C, which created the consulta vecinal as a mechanism for citizenship participation at the district level. The ordinance was 
based on international, national and municipal rights, and on laws regarding citizen participation (international treaties, national and municipal laws, constitutional articles and the Environment Code), setting the basic legal structure that would later be used in all following consultations in Peru. While ILO 169 was not referenced in the Tambogrande consultation ordinance (it was added in the following Majaz/Río Blanco municipal ordinances), it was used in activist discourses (Fulmer, 2011).

The National Office of Electoral Processes initially recognized the consulta and agreed to provide support. However, a formal complaint of unconstitutionality and illegality by the Ministry of Energy and Mines (MEM) reduced the final involvement of the office to advising and lending election materials (National Electoral Office, 2002). The technical advice of national and transnational groups and the financial collaboration of transnational organizations such as OXFAM were key to conducting the consultation (Portugal Mendoza, 2005; Bebbington, Humphreys Bebbington and Bury, 2011). Moreover, organizations such as the Mineral Policy Center, the Environmental Mining Council of British Columbia, OXFAM, and Friends of the Earth from Costa Rica and Ecuador contributed to building the legitimacy of the consultation by acting as observers, supporting and disseminating the experience (Muradian, Martinez-Alier and Correa, 2003).

On 2 June 2002, the consulta calling all district inhabitants was held and resulted in a massive rejection of the mining project (Portugal Mendoza, 2005). The participation mechanism followed the same procedures of a regular election (secret vote, registered voters, ballot boxes, etc.) (see Table 11.1). The consultation was not recognized either by the mining company or by the national government, which claimed that the EIA formal assessment was the legally binding decision-making process. The following month the Frente prevented three public audiences through organized protests. Finally, the public company revoked the Manhattan mining licence based on administrative grounds, thereby suspending the project. In November 2002 the president of the Frente, Francisco Ojeda, won the municipal elections (Portugal Mendoza, 2005).

\section{Majaz/Río Blanco conflict (Piura, Peru)}

As the Tambograde struggle was coming to an end, a new and relevant mining conflict was emerging nearby in the provinces of Ayabaca and Huancabamba (Piura Highlands) concerning the exploration of a copper-molybdenum mining deposit by a subsidiary of Monterrico Metals. The conflict of Tambogrande not only contributed 
to introducing mining scepticism in the region but was also a source of experience and support for local groups and authorities in this new struggle (Diez Hurtado, 2007; Bebbington, 2012a). For instance, the group of organizations and individuals supporting the Frente in Tambogrande - then formalized as Red Muqui - later in the conflict fostered the formation of the Majaz Support Group to create a bridge of experience, technical expertise and strategies among movements (Bebbington, 2012a).

The Majaz mining project was located in the peasant communities of Segunda y Cajas and Yanta (comunidades campesinas), lands that are administered under particular institutional arrangements legally recognized by the state (Bebbington, 2012a). The company did not comply with the required approval of the community assembly, triggering rejection and formal complaints (Bebbington et al., 2007).

In 2004, two "massive" mobilizations were conducted involving thousands of peasants concerned by the environmental (water), economic (agriculture, tourism) and social (land access) impacts of the mining project and its lack of recognition of local institutions. These protests resulted in police clashes, injuries and the death of two peasants, Remberto Herrero (April 2004) and Melanio García Gonzalez (July 2005) (Bebbington, 2012a). From 2004 to 2007, local activists denounced cases of activist kidnapping, tortures and persistent criminalization (discredit campaigns, unjustified imprisonment, legal prosecution) that even reached the UK justice courts (OXFAM, 2007, 2009; Cobain, 2009).

In 2005, mayors, local leaders and social organizations fostered the formation of the Frente por el Desarrollo Sostenible de la Frontera Norte del Perú (FDSFNP). The organization, critical of the mining project and the role of the national government, was composed of provincial and district government representatives, peasant communities, rondas campesinas, defence fronts from Huancabamba, Ayabaca, Tambogrande, and other anti-mining groups from the region.

Tension and distrust rose as negotiation attempts by the regional and national governments were failing and the government issued measures to limit public participation rights (Diez Hurtado, 2007; Red Muqui, 2009; Bebbington, 2012a). In this context, a consultation was promoted. As in Tambogrande, the consultation was seen as a peaceful channel of participation that would ease local tensions. The municipalities of Ayabaca and Huancabamba approved municipal ordinances, calling for a consulta vecinal (Bebbington, 2012a). The consulta resulted in a $94.5 \%$ rejection of mining activities in the district. 
While in Tambogrande the national government minimized the weight of the consultation, in this instance it actively tried to prevent it. A vociferous campaign criminalized the consultation and its proponents, stating that the referendum was illegal, communist and politically manipulated by international NGOs that intended to delay the country's development (OXFAM, 2007; McGee, 2008). However, the Peruvian ombudsman and the human rights national council of the Justice Ministry declared that, even if this mechanism was non-binding, it was legal under constitutional law (OXFAM, 2009; Red Muqui, 2009; CISDE-ALAI, 2009). Moreover, the Majaz consultation led the national ombudsman of Peru to initiate a process of regulation of indigenous consultation rights. What is more, both in Majaz and Tambogrande (and in Esquel, Argentina), mining activities were halted and therefore became examples of successful cases.

Toquepala expansion project (Candarave), Tía María project (Islay, Arequipa), Kañariaco project (Lambayeque) in Peru

After these two consultations in Piura (North of Peru), there were three others on the south and central coast of Peru, where national organizations and networks played a key role in spreading the experience and providing support. The following consultation in Candarave (2008, Tacna region, Atacama Desert) is different from previous cases because it took place in an area with ongoing large-scale mining activities. The conflict that led to the consultation emerged when the mining company started negotiations to expand its water-use permits. Local and provincial governments, the irrigation users (Junta de usuarios de riego) and the local fronts of defence opposed new permits. They pointed to the need to decrease mining water use due to a regional water scarcity crisis that was affecting agricultural production and forcing peasant outmigration, and to the need to compensate for these impacts. In January 2008 the mayor of Candarave called for a consulta vecinal (Municipal Ordinance No. 001-2008-MPC/A) with the support of the provincial governor, local defence fronts and the Junta de Aguas. The consulta had observers from national and international NGOs who also provided technical support (Radio Uno, 2008). Consultation participants (67\% of eligible voters) answered two questions: $92 \%$ rejected new mining activities, and $94 \%$ opposed the use of underground and superficial water for mining activities.

The fourth mining consulta in Peru occurred in 2009 in the province of Islay (Arequipa Department). Islay is a dry region inhabited by peasants and indigenous groups. The conflict emerged in 2008, with the 
Southern Copper Peru Corporation Tía María large-scale copper mine project (Gutierrez Zeballos, 2011). Concerns regarding impacts on water availability and local livelihoods fostered the formation of the Frente Amplio de Defensa del Medio Ambiente y Recursos Naturales. This movement led to the organization of a regional front with the support of local groups, the mayor of Valdivia and national organizations such as the CONACAMI, Cooperacción, Red Muqui and the Coordinadora Andina de Organizaciones Indígenas (Gutiérrez Zeballos, 2011; Red Muqui, 2011).

On 27 September 2009, the six districts of Islay conducted a consulta vecinal. The provincial mayor refused to call for a provincial referendum. In some districts, consultations were called by local mayors who issued ordinances. In other districts, consultations were led by social movements, following the same procedures (CAOI, 2009; Gutiérrez Zeballos, 2011). The process was observed by a national congressman, members of the Flemish NGO Broederlijk Delen, and the Peruvian NGOs Transparencia Civil and CONACAMI (Márquez, 2009). The average turnout was $48.5 \%$ (considering the districts where voter lists were available), and $93-98 \%$ opposed the Tía María project.

The national government did not recognize the referendum and, some months later, called for a public audience to present the project's EIA. With the assistance of national and transnational organizations, around 3,000 technical comments on the EIA project were submitted. Moreover, a series of regional strikes were organized as dialogue spaces were perceived as sterile. These strikes were marked by hard police repression, activist criminalization, three deaths and more than 400 injuries (Gutiérrez Zeballos, 2011). In the midst of this violence, a report by the United Nations Office for Project Services, requested by the government and communities as an "independent" review, concluded that the EIA had serious deficiencies (UNOPS/PNUMA, 2011), forcing the MEM to suspend the project.

The fifth consulta of Perú took place in 2012 in the northern district of Kañaris (region of Lambayeque). The Kañariaco mining project was a large-scale copper mine, in exploration stages, owned by the junior Canadian company Candente Copper Peru SA. The project was located in a cloud forest area inhabited and cultivated by two Quechuaspeaking communities (municipality of Kañaris, 2012). In an assembly in 2012, the community of San Juan de Kañaris decided to conduct a consulta comunal (community consultation) (Fedepaz, 2013). The mining company and the MEM claimed that a consultation had already been conducted following official procedures. 
The community consultation followed the procedures of regular communal elections (secret, registered voters) without the support of local governments; the result was a $91 \%$ mining rejection (1,896 votes, $47.4 \%$ turnout). The process was supported and observed by CONCAMI, the Red Muqui and leaders of local organizations. The regional governor, the Ministry of Agriculture, and representatives of regional offices of development and production, and energy and mines, also participated as observers (Servindi, 2012).

When this consultation occurred, the national government was promoting a law to regulate indigenous consultation rights. The question of whether the Kañaris are peasant or indigenous, and hence entitled to FPIC according to ILO 169, triggered a wide debate (Greenspan, 2013). While the national ombudsman and transnational indigenous groups recognize the FPIC for Kañaris, the government denies this right and claims that the government consultation is the valid one. In 2013 the Candente mining company stopped mining exploration, pointing to low copper prices as the reason.

\section{Ecuador, Kimsakocha project (Azuay)}

In October 2011 the first mining community consultation of Ecuador took place. The conflict arose from an open-pit project owned by a junior Canadian company. Concerns rose regarding the impact on water resources among indigenous and peasant groups located downstream from the project area (Pérez Guartambel, 2012). The idea to conduct a consultation emerged in the context of growing pressure from the national government to promote mining activities in the country, in the midst of verbal and legal delegitimation and criminalization campaigns against Ecuadorian indigenous and anti-mining activists (interview with local activist, 2012). Moreover, local indigenous and peasant leaders were in contact with Latin American indigenous, anti-mining and human rights movements, in particular from Ecuador and Peru (interview with national anti-mining movement leader, 2012). In June 2011, local indigenous leaders led the organization of a continental peoples meeting with a strong emphasis on the impact of mining agendas on the environment and indigenous groups (Pérez Guartambel, 2012).

A community consultation was called by the Junta de Aguas, an indigenous and peasant organization that administers access to household water. The consultation was grounded in ILO 169, the UN Declaration on the Rights of Indigenous People and the Ecuadorian Constitution (Pérez Guartambel, 2012). The vote was carried out in the parishes of Victoria del Portete and Tarqui. The organization was led 
by local leaders of the Federation of Indigenous and Peasant Organizations of Azuay, with the support of national indigenous organizations (Ecuador Runakunapak Rikcharimuy/Movement of the Indigenous People of Ecuador (ECUARUNARI), La Confederación de Nacionalidades Indígenas del Ecuador/Confederation of Indigenous Nationalities of Ecuador (CONAIE)) and the mayor of Victoria del Portete. The consultation followed the Junta de Aguas election procedures: one vote per water right (a family can have more than one right). The vote was secret and for registered water right owners (head of family, not individuals). The consultation had national and international observers from organizations and the national ombudsman office. Days before the consultation, newspaper pages and leaflets calling people not to vote were distributed. There was a $67 \%$ turnout with a $92.3 \%$ opposition to mining activities. Provincial and national governments did not recognize the vote and led a strong, discrediting campaign.

\section{Argentina}

\section{Esquel project (Chubut)}

The second consultation conducted in Latin America took place in Esquel in March 2003. The city of Esquel (28,089 inhabitants) is a main settlement of Argentinean Patagonia, an arid region also inhabited by Mapuche indigenous communities. In 2002 some $25 \%$ of the population were unemployed and $20 \%$ were under the poverty line. The arrival of Meridian Gold, a US junior mining company, with the intention to extract a gold and silver deposit located $6.5 \mathrm{~km}$ away from the city triggered the first mining conflict in the country.

The use of cyanide leaching techniques and the risks of water pollution in a water-scarce environment stirred initial concerns. The perception that the urgency to approve the project was undermining the quality of the technical assessment and was excluding local concerns led to the formation of a neighbours' assembly (Asamblea de Vecinos Autoconvocados (AVA)) opposed to the mine. The AVA brought together neighbours and organizations with different backgrounds, specialists in law, chemistry, medicine, geography, journalism and education, Mapuche groups and inhabitants of Esquel's poorer areas who became key information channels to marginal areas of the city. The movement deployed a range of strategies, from legal and administrative queries to mobilizations, technical arguments and advocacy networking. As the AVA jumped scales, contacting and obtaining the support of regional, national and international activists, organizations and networks, the 
Esquel conflict started to be understood as part of an environmentally unjust process affecting many communities in Latin America (Urkidi and Walter, 2011).

Members of the AVA became acquainted with Tambogrande's consultation via the internet. The AVA also established contacts with the Mining Policy Center (now Earthworks), an NGO that supported the Tambogrande consultation and that would later finance (along with Greenpeace Argentina) the visit of an American hydrogeologist, who had also been in Tambogrande, to Esquel (Colao and Claps, 2005).

Two representatives of the local Deliberative Council, close to the AVA, presented a municipal ordinance proposal to call for a consulta popular (popular consultation/referendum) using a legal mechanism present in the provincial constitution. While the proposal was initially rejected, the mounting tension in Esquel fostered its approval by most political parties as a way to pacify local unrest.

A few days after the consulta popular, which resulted in an $81 \%$ rejection of the mining project (75\% turnout), mining activities were halted and the Chubut legislature approved a provincial ban on open-pit mining. The Esquel case became a national referent (Svampa and Antonelli, 2009; Walter and Martinez-Alier, 2010). The AVA created an online platform (www.noalamina.org) that is still a key source of information for Argentinean and Latin American activists.

The Esquel case showed the strong political power that a non-binding consultation could have. In the years that followed, as mining investments were rising, more EJMs tried to foster similar consultations. In particular, the Government of the Province of Catamarca, the poorest province of Argentina where the oldest and largest mine operates ( $\mathrm{La}$ Alumbrera), managed to stop at least three attempts of consultation in Tinogasta and Andalgalá in court.

\section{Lonco project (Neuquén)}

The second consultation in Argentina took place in the municipality of Loncopue. After a series of legal setbacks and different intimidation campaigns aimed at social movements and Mapuche indigenous communities, exploration activities were advancing without permits or consultation procedures. A local priest became involved and brought the matter to the town, connecting the urban movements with rural indigenous groups. A lawyer and anti-mining activist from Esquel, who was living in Loncopue, transferred his professional and activist experience to the emerging movement, advising and supporting the legal strategy (Yappert, 2009). 
The call for a binding referendum to approve/reject a municipal law forbidding large-scale open-cast mining activities was fostered by Mapuche communities, neighbourhood assemblies, environmental groups and, as in Esquel, some politicians whose political parties were pro-mining at the provincial and national levels but who aligned themselves with anti-mining groups locally. With a $72 \%$ participation turnout, $82 \%$ voted in favour of a mining prohibition, but the provincial government presented a legal claim of unconstitutionality to disable the referendum (Yappert, 2009).

\section{Guatemala and Colombia}

Guatemala: Sipakapa, Escobal and the wave of consultas in West Guatemala

The third Latin America bottom-up mining consultation after Tambogrande and Esquel (Argentina) occurred in Sipakapa (Guatemalan highlands) in June 2005. In 2003, Montana (now owned by the Canadian GoldCorp) obtained the exploitation permit for the Marlin gold mine in the municipalities of Sipakapa and San Miguel Ixtahuacan. These municipalities are inhabited by peasants who mostly identify themselves as indigenous. In Sipakapa, $87 \%$ live in relative poverty and $33 \%$ in absolute poverty (SEGEPLAN, 2002).

Research and interviews underline the fact that the first meetings held by the company with local groups and leaders were non-transparent, arbitrary and pro-mining (Van de Sandt, 2009; Urkidi, 2011). The opposition to mining in Sipakapa was born from the mistrust that arose among many community leaders in regard to information activities. Indigenous leaders met local priests and national groups (Movimiento de Trabajadores Campesinos, MadreSelva, Centro de Acción Legal Ambiental y Social de Guatemala (CALAS)) in order to get information about mining (Van de Sandt, 2009). These national organizations were already within Latin American networks (e.g. MadreSelva within OilWatch) and distributed information about the environmental impacts of mining activities. Local leaders from Sipakapa visited other gold-mining areas in Central America, such as Valle de Siria in Honduras, and got in touch with regional networks against mining (e.g. Central American Anti-Mining Network).

In December 2004 a community that blocked the passage of a truck heading to the mine in a neighbouring province was strongly repressed by police and military forces, resulting in the death of the peasant Raul Castro Bocel (Prensa Libre, 18 January 2005; Castagnino, 2006). The 
public resonance of these events forced the mayor of Sipakapa (in favour of mining) to arrange a public meeting to discuss the mining issue. This meeting led to a municipality agreement to conduct a consultation, based on the Municipal Code (2002) and ILO 169. The idea to conduct a consultation had been circulating since the beginning of 2004, born from an Italian priest who was acquainted with the Tambogrande experience (Van de Sandt, 2009).

The consultation was organized through the articulation of local, national and international organizations: the Municipal Development Council (Consejo Municipal de Desarrollo (COMUDE)), the parish and its catechists, the Linguistic Community of Sipakapa, the local justice of the peace, MadreSelva, the National Association of Maya Lawyers, the Catholic Church of San Marcos, and the Indigenous Advocacy of Human Rights, among others. National and international observers and human right activists were called in to verify the process. The Guatemalan Constitutional Court rejected an appeal of Montana to ban the consultation. On the same day of the consultation, flyers saying that the consulta was not going to occur were distributed in Sipakapa, presumably as a boycott by Montana.

However, $45 \%$ of the registered electorate took part in the consultation and $98 \%$ voted against mining. The voting was carried out in each community; some voted by a show of hands, others by secret ballot. In 2007 the Guatemalan Constitutional Court declared that the Sipakapa consultation was valid under ILO 169 and the Municipal Code, but that it was non-binding since such conventions and laws were imprecise and not coherent with the constitution, and also because mining activities were of national public interest. Hence the municipality of Sipakapa had no authority to decide on the matter (Xiloj and Porras, 2008).

The Marlin mine was in full operation in 2013, despite the consultation and different legal demands in relation to environmental impacts and the violation of human rights. ${ }^{1}$ However, the process of Sipakapa was a milestone in the Guatemalan resistance against mining. The experience has been reproduced in 56 other consultations on metal mining in the country from 2005 to 2012 and more than 600.000 people have taken part in them, becoming one of the most relevant political processes of recent years in the country. A documentary on the Sipakapa consulta (Revenga, 2005) played a central role in spreading the experience throughout Guatemala and Latin America.

Some 52 of those 57 consultations occurred in western Guatemala and most of them in the highlands, as part of a regional campaign to 
reject mining activities. The Western People's Council (WPC), where the Huehuetenango Natural Resources Assembly had a central role, led the spread and organization of consultations. The WPC is a regional network organized in 2008 as a coalition of provincial organizations working in the defence of natural resources and local leaders of the municipalities that have held consultations. Its main objective is to develop a community-based strategy against mining. There are also national and international networks and $\mathrm{NGOs}^{2}$ supporting the development of the consultations. However, one key characteristic of the Guatemalan process is the synergies between the anti-mining movement and the municipal governments in the organization of most consultations, and the active incorporation of local leaders in the regional network (Mérida and Krenmayr, 2010; Urkidi, 2011).

More recently, other cases of consultations that are not directly related to the WPC work are emerging in other areas of Guatemala. The consultation on the Escobal project in Santa Rosa is not part of the wave of consultations of western Guatemala, even if it has also been influenced by the Sipakapa experience. The context of Santa Rosa differs from the highlands, as most of its population are non-indigenous. There are, however, some Xinca communities. The conflict arose in 2010 when Tahoe Resources and Goldcorp were to start a metal mine in the area that might affect a nearby lake and its related water resources. A local committee was organized and, between 2011 and 2012, four consultations were developed in nearby towns with the support of the regional diocese, a national environmental organization (MadreSelva) and local governments. However, no consultation has been permitted in San Rafael Las Flores; the mine is in operation, the local population are highly divided, and violent events and criminalization processes have taken place over the last few years (OCMAL, 2013).

Apart from Sipakapa and Santa Rosa, the rest of the Guatemalan consultations are not associated with imminent mining projects but with exploration or research licences, so that they could be understood as preventative consultations. Indeed, no new exploration licences were granted in the country from 2008 to 2012 . Table 11.2 presents more details about the cases of preventative consultations of Guatemala. The Guatemalan Government has not accepted community referendums and has proposed to regulate them with a specific law (Prensa Libre, 23/02/2011). The WPC defends that the current legal framework is sufficient to accept the consultations and their results, and that further regulations would just lead to more restrictive conditions for participation (Nisgua, 2011; Prensa Libre, 23/02/2011). 
The Guatemalan anti-mining movement seeks to be inclusive in many senses, resulting in heterogeneous consulting processes. Mainly indigenous but also non-indigenous communities have been consulted (these last ones not appealing to ILO 169 but just to the Municipal Code (2002)), by secret ballot or by show of hands, in municipal or just communitarian consultas. In some cases, mainly in Huehuetenango, non-registered people have been able to take part in indigenous community meetings. This has led to greater participation of women than in other voting processes since women are proportionally less frequently registered than men in Guatemala (Mérida and Krenmayr, 2010). Such consultas have also spread to other extractive projects in Guatemala, such as hydroelectricity.

\section{Colombia, Mandé Norte project (Carmen de Darién, Chocó)}

Between 24 and 28 February 2009, the first community consultation on mining in Colombia took place. The conflict started with the arrival of Muriel Mining (Río Tinto and other companies), and the initial consultation activities led by the government and company to obtain the communities' approval to explore for copper, gold and molybdenum ores. Exploration sites were located in Afro-descendant and indigenous peoples' lands, including their homes and sacred areas, in the departments of Antioquia and Chocó. Indigenous and Afro-descendant communities started to search for information and contacted a national church organization working in the area. A support group was created, bringing information, documentaries (e.g. the Sipakapa case) and activists from other countries and communities to Carmen de Darién (Jahncke Benavente and Meza, 2010). Communities claimed that the official consultation process was not adequately conducted, excluding affected communities and endangering their livelihoods. As a reaction to local unrest, the national government militarized mining areas, intimidating and limiting community access (Jahncke Benavente and Meza, 2010; Movice, 2012).

Communities, inspired by the Sipakapa experience, promoted the organization as an interethnic consultation, following their own procedures (own language, registered, older than 14 years old). Human rights, indigenous, church and anti-mining organization representatives from Colombia, Paraguay, Honduras, Guatemala, Germany and Canada observed the process (CENSAT, 2009).

The consultation was grounded on international and national indigenous consultation rights, including the Colombian Constitution's special consideration for indigenous consultation rights. The legality and 
legitimacy of the process was confirmed by an important verdict (T-769, 2009) of the Colombian Constitutional Court, which led to the suspension of the project. Nevertheless, in the year that followed, campaigns to delegitimize local communities and further intimidation actions were conducted by the government in the area. In January 2010 the Colombian army conducted air bombings (Movice, 2012).

Consultation attempts have also been deployed by other nonindigenous communities in Colombia. During 2011, social movements in the department of Santander tried to conduct a popular consultation framed around the protection of water to stop gold-mining developments in upstream Páramo areas. This initiative was politically blocked (Comité por la defensa del agua y el páramo de Santurbán, 2012). Recently, in July 2013, the municipality of Las Piedras (Tolima region) conducted a popular consultation on mining activities, resulting in a $60 \%$ participation and $99 \%$ rejection of a large-scale mining project to be carried out by Anglo Gold Ashanti (EJOLT, 2013).

\section{Discussion}

The cases of consultation analysed in this chapter represent an innovative governance experience that seeks to ensure inclusive participation in mining activities. Moreover, this governance perspective goes beyond local/global, formal/informal, state/non-state divides. These points lead to four aspects of consultations, which are elaborated in this discussion.

\section{Contexts: Conflicts, exclusion, criminalization and violence}

The mining conflicts that led to consultations involved high-stake struggles. Mining disputes revolve around how the spatial and social distribution of uncertain benefits and impacts of mining activities are defined, and which are the legitimate scales of participation and decision-making to govern this activity. Consultations are neither the first nor the only action deployed by EJMs, but instead are promoted alongside a range of strategies (e.g. negotiations, mobilizations, legal and technical allegations, dissemination activities) aimed at influencing and challenging centralized mining governance institutions.

The discourses deployed by anti-mining movements in our cases reflect Schlosberg's (2007) key dimensions of environmental justice: recognition, distribution and participation. Anti-mining groups see the approval of mining projects as the misrecognition of their material and cultural dependence on land and water, and also as a disregard of their views and customary procedures (Muradian, Martinez-Alier and Correa, 2003; Haarstad and Floysand, 2007). 
Social movements opposing mining activities claim that developing mining activities jeopardizes local (and supralocal) livelihoods. Communities in Peru, Guatemala, Colombia and Ecuador signal the risks to their livelihoods, which are dependent on agriculture, cattle and forests. Concerns about health also appear, with high relevance in Esquel (Argentina) regarding cyanide use. Worries about water quality, and availability for local economic activities and household use, are common to all studied cases.

While the affected communities signal such concerns as grounds to redraft or even stop a mining project and national mining plans, governments and companies claim that these decisions are not for local communities to make. Central governments argue that mining is an issue of national interest and experts within a national decision-making process should have the last word. Governments and mining companies frame local alarm as an exaggeration that undermines the positive impacts of mining. Moreover, critical communities' and EJM's views are being labelled by Latin American national governments as irrational, ignorant, anti-development, politically driven, promoted by foreigners' interests or by a radical, subversive environmentalism (Bebbington, 2012b), hand in hand with criminalization processes (OCMAL, 2011).

Official participation arenas become frustrating spaces given the partial information that is shared and the powerless participation modes they offer (Cole and Foster, 2001). As decision-making procedures are unable to address local communities' concerns, disputes form around these procedures and their decisions (Muradian, Martinez-Alier and Correa, 2003; Suryanata and Umemoto, 2005; Walter and MartinezAlier, 2010; Urkidi and Walter, 2011). It is becoming increasingly common for EJMs to prevent or boycott public audiences, as these are seen as an empty requisite for project approval (Jahncke Benavente and Meza, 2010). There were cases of boycotts of public audiences in Tambogrande, Toquepala, Tía María, Esquel and Loncopue. Indigenous communities rejected and misrecognized the alleged consultation processes led by mining companies and governments in Peru, Colombia and Guatemala. In Ecuador and Argentina, indigenous communities claimed that formal consultation never occurred (Urkidi and Walter, 2011; Pérez Guartambel, 2012).

Furthermore, one of the findings of this research has been the role played by violence in the fostering of consultations. Human Rights claims have been identified as a particular root of Latin American EJMs (Carruthers, 2008). Mining referenda have emerged in contexts of repression and criminalization of activists, where concerns regarding the physical and psychological integrity of activists were rising. In this 
line, consultations can be seen as an innovative form of protest that aims to foster participation, promoting a democratic setting that protects its participants. These consultations have succeeded in pacifying local tensions, at least for a while.

While contexts of activist and protest criminalization and repression are not new in mining struggles, the particularity of these cases has been the ability of EJM to transform a risky protest environment into a democratic participation process. To do so, EJMs have constructed a hybrid participation institution.

\section{Community consultations: A hybrid institution}

Latin American mining consultations/referenda are based on the claim that communities - whether indigenous or not - have the right to participate in high-stake decisions that affect their livelihoods, a right deemed legitimate by affected communities. This right is recognized in a variety of indigenous and non-indigenous, international, national and municipal norms and rights (Jahnchke Benavente and Meza, 2010; Fulmer, 2011). However, how participation is framed by regulations and actors varies widely, being mostly informing and non-binding. As analysed by Arnstein (1969) in his eight-rung participation ladder ((1) manipulation, (2) therapy, (3) informing, (4) consultation, (5) placation, (6) partnership, (7) delegated power and (8) citizen control), there are different levels of exclusion/involvement and empowerment. As pointed out by Arnstein, as we step down the ladder, frustration rises. Communities are struggling to climb this ladder.

Community consultations reclaim and rebuild the right of affected communities to participate, in meaningful and empowering ways, in decisions regarding high-impact activities that affect them. With this aim, in each context, communities strive for local participation rights appealing to, combining and reshuffling available regulations, rights and local traditions. This process of institutional bricolage draws on a particular mix of formal and informal, and modern and traditional, institutions according to the particular context.

For instance, communities are expanding and resignifying, in their discourse and practices, the way "consultation" is framed in ILO 169 and the United Nations Declaration on the Rights of Indigenous People - forcing new debates about the convention's reach (McGee, 2008; Fulmer, 2011). ILO 169 asserts that consultations should be conducted by states. However, the studied consultations are not organized by the central government (Jahncke Benavente and Meza, 2010; Fulmer, 2011). Community consultations appeal to ILO 169 consultation rights, 
stretching the convention's reach according to what is considered just and legitimate by affected communities. In a similar vein, the way in which consultations appeal to national, municipal and international participation laws and rights in order to allow for a local referenda on mining challenges the national-government scale monopoly in mining decisions.

In each context, this hybrid institution is legitimized by reference to tradition and/or to the social perception of what are the acceptable ways of doing things (Cleaver et al., 2013). A relevant source of (internal and external) legitimacy of consultas/referenda is rooted in the procedures used to consult people that appeal to democratic values and to indigenous consultation rights. In most cases, communities put in place hybrid procedures that combine democratic participation institutions (e.g. official election procedures), indigenous customary rights, and experiences/lessons from previous consultations. In most consultations, including many indigenous communities in Guatemala, the consultation followed the same procedures as those of a regular election: formal call to vote, registered voters, the secret vote and the quality of the process as certified by external observers, as in Tambogrande. In Sipakapa, each of the 13 communities consulted chose its own procedure: some followed a traditional Western election format, while others voted by a show of hands or other formats. However, the consultation was called by the municipality and all members of the municipality could vote (even non-indigenous). In Sipakapa, indigenous customary votes were the most criticized by the government and by companies that claimed that their result could be manipulated (Fulmer, 2011). The consultation conducted by indigenous groups in Colombia followed the example of Sipakapa by merging procedures.

Some forms of (hybrid) governance that would include diverse social actors and visions a priori have been criticized because they continue to exclude disempowered groups (Ford, 2003; Cleaver et al., 2013). In contrast, consultations are organized by, and take into account, marginalized groups such as indigenous peoples, women and peasants. As a result, consultations usually stretch the reach of formal and informal institutions in order to foster local participation.

Consultations are more than the sum of existing regulations and rights but, while grounded on these, they reclaim their scope and meaning based on what is deemed legitimate and just by local communities. Moreover, the significance of community consultations is that communities are not only mobilizing and discursively struggling to contest the governance of mining activities but are also deploying innovative 
strategies to demand empowering and democratic participatory institutions. The community consultations studied here are a form of political mobilization, a form of protest grounded on democratic and indigenous, formal and informal institutions.

\section{The roles of movements, governments and state bodies}

While EJMs have played a key role in the emergence and spread of consultations, a particular feature of community consultations has been the role played by local governments. Community consultations combine the formal and informal capabilities (i.e. rule-making, management, communication) and different forms of power (e.g. legitimacy, networks, resources, trust) of social movements and local governments.

Cases of consultations conducted without alliances with local governments are the exception. In some cases local governments rapidly align with social movements or even play a central role in the formation of movements critical of mining activities (e.g. Majaz, Toquepala, Guatemala's wave of consultations). In other cases, local governments change their position as conflicts unfold and finally allow or support consultations in order to preserve local governability or local power (e.g. Esquel, Sipacapa), sometimes adopting a position that differs from their national political parties.

However, the legitimacy of consultations is in dispute by different actors within states and governments. While national governments and mining departments reject, ignore or criminalize (define as illegal acts) these participatory events, some local and provincial governments - as well as national and regional departments, authorities and tribunals recognize this participation institution (e.g. National Electoral Office, Constitutional Court, ombudsman, Human Rights National Councils, Ministry of the Environment).

The alliance with local governments was key to building the legitimacy of consultations (Red Muqui, 2009), framing them as a formal local (and democratic) participation institution, not a mere anti-mining social movement strategy (Muradian, Martinez-Alier and Correa, 2003). The fact that the first cases of consultations were conducted with the support of local ordinances contributed to building the grounds for legitimating the following wave of consultations, conducted with or without this formal support (e.g. some municipalities in the Tía María consultation in Peru and the Kimsakocha case in Ecuador). Moreover, the involvement of social movements reduced, in some places, the distrust that many rural communities have in relation to government bodies, including municipalities. In Guatemalan consultations, the fact 
that actors not directly related to the municipal government were also promoting the consultas was pointed out as a source of local trust and willingness to participate (interviews Guatemala 2009; Mérida and Krenmayr, 2010). We could also say that the legitimacy of consultations is, in part, both a cause and a consequence of the hybrid alliances formed between local governments and social movements.

The involvement of local governments and the diverse positions adopted within state and government bodies regarding community consultations reflect the heterogeneity of interests and values across these structures. This feature of consultations points to the need to further problematize the role of governments and the state in environmental governance frameworks. Hybrid institutions led by civil society, such as community consultations, do not necessarily aim to "bypass governments" (as pointed out by Delmas and Young, 2009) but, on the contrary, to anchor part of its legitimacy in some of its bodies (local governments).

Currently, the strength of the consultation's legitimacy grounded in its "legality" (i.e. formal institutional support) is becoming a weakness as the struggle is now revolving around the formalization of consultation rights (i.e. regulating consultation procedures) by central governments, with risks of co-optation, exclusion and denaturalization of the institution.

\section{A multiscalar institutional bricolage}

Finally, we would like to point out that, while consultations could be framed as a hybrid institution that exemplifies a process of governance from "below" (Paterson, Humphreys and Pettiford, 2003), the strength and legitimacy of this institution is multiscalar. Analysing the spread of consultations in Latin America, we identify that this institution was fostered hand in hand with a diversity of spatial processes that have been key in its emergence, spread and legitimation in Latin America. Along these lines, consultations can be seen as the result of a dynamic multiscalar process of institutional bricolage.

Mining consultations are promoted by social movements composed of a myriad of groups, including indigenous and peasants' movements, farmers, (urban) professionals, local priests, teachers, community leaders and NGOs. As mining conflicts unfolded, these social movements engaged with networks and organizations (e.g. environmental, antimining, human rights, indigenous, Catholic) that move across multiple geographical scales. In the wave of consultations in Guatemala, national anti-mining networks fostered the participation of local actors and 
leaders. These networks circulate information, experiences and strategies, and promote the mobility of activists to learn and share experiences among communities, to Latin America and international forums, to foreign (e.g. UK courts in the Majaz case) and international tribunals (e.g. Sipakapa to the Inter-American Commission on Human Rights).

Additionally, among the EJMs and networks driving the spread of consultations, some were born from the first mining consultation experiences: Tambogrande, Esquel and Sipakapa. These first cases are relevant mining conflicts at national and transnational scales and have become milestones in the mining consultation processes in Latin America and in their own countries. Red Muqui, born from the Tambogrande conflict, was a key provider of information, experience and materials for the Majaz/Río Blanco case and following consultations. The "Noalamina" platform, coordinated by the Esquel anti-mining movement, is a key provider of information and resources for Latin American communities. In Guatemala, the great multiplication of mining consultations is partially grounded in the national and international repercussion of Sipakapa's experience. With the support of different national NGOs and associations, two regional networks were created around mining and hydropower conflicts (Huehuetenango Natural Resources Assembly and the Western Peoples Council). There has been an experience-sharing process, where new consultations have been organized by knowing and learning from previous ones, via these national and transnational organizations and networks (Red Muqui, 2009; Jahncke Benavente and Meza, 2010).

Organizations and networks have not only played a key role in spreading the experience of previous consultations but also provided logistical, technical and sometimes financial resources. A range of transnational actors have also supported consultations as observers, contributing to building the international legitimacy of these processes. OXFAM, Friends of the Earth, Greenpeace, the Mineral Policy Centre, Peace Brigades International, Nisgua, Catapa, Rigths Action in Sipakapa and Mining Watch are among the international observers that have been present in Latin American mining consultations.

Furthermore, as consultation experiences multiplied in Latin America, national and transnational networks have deployed efforts to systematize and strengthen the ongoing experience and its lessons, by organizing international events (e.g. Bi-national encounter EcuadorPeru on Community Consultations, 28 February 2012) and elaborating reports (e.g. McGee, 2008; CISDE-ALAI, 2009; Jahncke Benavente and Meza, 2010; Mérida and Krenmayr, 2010; Duthie, 2012). National and 
transnational movements have also supported legal strategies - to defend the legality of consultations and condemn human rights abuses at national and international tribunals (Constitutional Court case in Colombia, Interamerican Human Right Commission presentation of Sipakapa), thus systematizing and denouncing the growing number of criminalization cases (e.g. OCMAL, 2011).

When considering how consultations have travelled among Latin American communities, we point out that the internet and documentaries are powerful transporters of testimonies and experiences among distant people and places. While the role of the internet has been discussed in previous studies (Bickerstaff and Agyeman, 2009), we also found that documentaries are significantly contributing to social learning processes.

Sipakapa's documentary was a key source of inspiration in the organization of the Embera Katio indigenous consultation in Carmen de Darien (Colombia, 2009) (interview with Colombian activist, Jahncke Benavente and Meza, 2010). An indigenous leader that led the consultation of Ecuador also underscored the relevance of videos and documentaries to explain the implications of large-scale mining activities. ${ }^{3}$ The documentaries on the Choropampa mercury spill in Cajamarca (Peru) and the cases of the Tambogrande and Sipakapa consultations have been widely distributed in the region (Choropampa: el precio del oro, 2002; Sipakapa no se vende, 2005; Tambogrande: mangos, muerte, minería, 2007). These and other documentaries have shown the impacts of large-scale mining activities and the strategies of anti-mining groups, contributing to a regional EJM learning process. In this regard we agree with Bickerstaff and Agyeman (2009) that there is a promising line of research to be explored in relation to the development of "assemblage" perspectives - coming from the actor-network theory (ANT) - when analysing how people, texts, machines, devices and discourses relate and collectively constitute environmental justice scales. How to conceptualize the role of these devices in processes of institutional bricolage could be explored in further detail.

Colombian activists highlight how Carmen de Darien's indigenous communities were moved to see - in the documentary on the Sipakapa consultation - other indigenous groups faced with similar struggles, telling similar histories and learning from their consultation experience (interview with Colombian activist). Documentaries played a central role in making affected communities acknowledge that their conflict was not local but simultaneously local, national, regional, global and 
structural. In this process, a common perspective is constructed and solidarity linkages are strengthened.

The construction, the spread and the sources of legitimacy of this hybrid institution (i.e. community consultations) are embedded in a complex and dynamic interplay of actors, discourses, networks and strategies that move among multiple scales. The political power of consultations is related to the ability of supralocal social movements to move and disseminate these events at multiple scales, creating new supports and reactions. Consultations, whether vecinal, popular, comunitaria or inter-étnica, are embedded in municipal, national and international norms and rights that are reclaimed by EJMs. In this regard, Latin American mining consultations are a multiscalar institution since they are constituted by (and constitutive of) actors, strategies, regulations and discourses rooted in different, multiple and changing scales.

\section{Conclusions}

The process of meeting, consulting and voting is part of the functioning of many indigenous and peasant communities and organizations in Latin America. However, the mining consultations studied in this chapter, while nurtured and legitimated by these traditions, are something different. Mining consultations constitute a common institution in the current Latin American anti-mining protest cycle. Consultations reclaim and resignify the right of the local population and indigenous peoples to participate, in empowering ways, in high-stake decisions affecting their lands and livelihoods. Consultations are put forward not just as a form of protest but also as a decision-making event that challenges official decision-making institutions. Moreover, consultations show how we should move beyond analytical polarizations and try to understand the tensions and dynamics in the process of governance hybridization through cross-scale interactions, discourses and practices.

\section{Notes}

1. In 2010 the Inter-American Commission on Human Rights ruled in favour of the precautionary closure of the project because of potentially harmful health and environmental impacts.

2. Mainly environmental and human rights associations and NGOs from Europe and Canada (CATAPA, Network in Solidarity with the People of Guatemala NISGUA or Rights Action, among many others).

3. Interview conducted by Sara Latorre and Stalin Herrera with local leader, shared with us. 


\section{References}

Arnstein, S.R. (1969) "A Ladder of Citizen Participation", JAIP 35(4): 216-224.

Bebbington, A. (2012a) "Social Conflict and Emergent Institutions. Hypotheses from Piura, Peru", in A. Bebbington (ed.), Extractive Industries, Social Conflict and Economic Development: Evidence from South America (London: Routledge), 67-88.

Bebbington, A. (2012b) "Underground Political Ecologies: The Second Annual Lecture of the Cultural and Political Ecology Specialty Group of the Association of American Geographers", Geoforum 43: 1152-1162.

Bebbington, A., Connarty, M., Coxshall, W., O'Shaughnessy, H. and Williams, M. (2007) Mining and Development in Peru. With Special Reference to the Rio Blanco Project (Piura: Peru Support Group).

Bebbington, A., Humphreys Bebbington, D. and Bury, J. (2011) "Federating and Defending Water, Territory and Extraction in the Andes", in R. Boelens, D. Getches and A. Guevara Gil (eds), Out of the Mainstream: The Politics of Water Rights and Identity in the Andes (London: Earthscan), 307-327.

Bickerstaff, K. and Agyeman, J. (2009) "Assembling Justice Spaces: The Scalar Networking of Environmental Justice in North-East England", Antipode 41(4): 781-806.

Bridge, G. (2004) "Mapping the Bonanza: Geographies of Mining Investment in an Era of Neo-Liberal Reform", Professional Geographer 56(3): 406-421.

Bullard, R. (1990) Dumping in Dixie: Race, Class, and Environmental Quality (Boulder, CO: Westview Press).

Bulkeley, H. (2005) "Reconfiguring Environmental Governance: Towards a Politics of Scale and Networks", Political Geography 24: 875-902.

Cabellos, E. and Boyd, S. (2007) Tambogrande: Mangos, Muerte, Minería, Documentary, Guarango Association, Peru.

CAOI (Coordinadora Andina de Organizaciones Indígenas) (2009) Seis Distritos de la Provincia Arequipeña de Islay se pronunciaron a través del Voto, http:// elecochasqui.wordpress.com/actualidad/setiembre-2009/caoi-seis-distritos-dela-provincia-arequipena-de-islay-se-pronunciaron-a-traves-del-voto-rechazo-alproyecto-minero-tia-maria-alcanza-el-97/, date accessed 10 January 2013.

Carruthers, D. (ed.) (2008) Environmental Justice in Latin America: Problems, Promise, and Practice (Cambridge, MA: MIT Press).

Castagnino, V. (2006) Metal Mining and Human Rights in Guatemala: The Marlin Mine in San Marcos (Guatemala: Peace Brigades International).

CENSAT (2009) Colombia: No a la Minería en Territorio Indígena, http://censat. org/component/content/article/314, date accessed 10 January 2013.

CISDE-ALAI (2009) América Latina: Riqueza Privada, Pobreza Pública (CISDE-ALAI).

Chaparro Avila, E. (2002) Actualización de la Compilación de Leyes Mineras de Catorce Países de América Latina y el Caribe, UUNN División de Recursos Naturales e Infraestructura ECLAC http://www.eclac.org/publicaciones/xml/6/ 10756/LCL1739-P-E.pdf, date accessed 10 January 2013.

Cleaver, F. (2001) "Institutional Bricolage, Conflict and Cooperation in Usangu, Tanzania", IDS Bulletin 32(4): 26-35.

Cleaver, F. (2002) "Reinventing Institutions: Bricolage and the Social Embeddedness of Natural Resource Management", The European Journal of Development Research 14(2): 11-30. 
Cleaver, F. (2012) Development Through Bricolage: Rethinking Institutions for Natural Resource Management (London: Routledge).

Cleaver, F., Franks, T., Maganga, F. and Hall, K. (2013) Beyond Negotiation?: Real Governance, Hybrid Institutions and Pastoralism in the Usangu Plains, Tanzania, Working paper 61 (London: King's College).

Cobain, I. (2009) "British Mining Company Faces Damages Claims Alter Allegations of Torture in Peru", The Guardian, 18 October 2009.

Comité por la Defensa del Agua y el Páramo de Santurbán (2012) Queja Presentada ante la Oficina del Ombudsman y Asesor en Materia de Observancia, http://www.aida-americas.org/es/release/queja-interpuesta-contra-el-financi amiento-de-mina-de-oro-en-fragiles-humedales-colombianos, date accessed 10 August 2013.

Colao, D. and Claps, L.M. (2005) Comunicación, Recursos Naturales y Comunidad en el Caso Esquel, Graduate Thesis (Buenos Aires: Universidad de Buenos Aires).

Cole, L.W. and Foster, S.R. (2001) From the Ground Up: Environmental Racism and the Rise of the Environmental Justice Movement (New York: University Press London).

De Echave, J., Diez, A., Huber, L., Revesz, B., Lanata, X.R. and Tanaka, M. (2009) Minería y Conflicto Social (Lima: Instituto de Estudios Peruanos).

Delmas, M.A. and Young O.R. (eds) (2009) Governance for the Environment (New York: Cambridge University Press).

Diez Hurtado, A. (2007) "Ronderos y Alcaldes en el Conflicto Minero de Río Blanco en Piura, Perú", in J. Bengoa (ed.), Territorios Rurales. Movimientos Sociales y Desarrollo Territorial Rural en América latina (Santiago de Chile: RIMISP).

Duthie, K. (2012) Local Votes and Mining in the Americas (Mining Watch Canada).

Ejolt (2013) A Letter from Piedras, Tolima, Colombia: Local Referendum Against Anto Gold Ashanti, Environmental Justice Organizations, Liabilities and Trade Project, http://www.ejolt.org/2013/09/a-letter-from-colombia/, date accessed 10 October 2013.

Fedepaz (2013) Kañaris, Última Comunidad de Habla Quechua en la Costa Peruana, realiza Consulta Comunal, Fundación Ecuménica para el desarrollo y la Paz, http://www.fedepaz.org/index.php?option=com_content\&task=view\& $\mathrm{id}=194 \&$ Itemid=18, date accessed 20 August 2013.

Ford, L.H. (2003) "Challenging Global Environmental Governance: Social Movement Agency and Global Civil Society", Global Environmental Politics 3: 120-134.

Fulmer, A. (2011) "La Consulta a los Pueblos Indígenas y su Evolución como Herramienta de Negociación Política en América Latina. Los Casos de Perú y Guatemala", Apuntes 68: 37-62.

Greenspan, E. (2013) Peru backslides on Indigenous Rights, Oxfam America, http://politicsofpoverty.oxfamamerica.org/2013/05/08/peru-backslides-onindigenous-rights/, date accessed 10 October 2013.

Gutiérrez Zeballos, P.J. (2011) "Las Razones de Lucha por el Valle del Tambo", in Cooperacción/Red Muqui/Frente Ambito de Defensa del Valle de Tambo/ Municipalidad Distrital de Dean Valdivia, Valle de Tambo-Islay. Territorio, Agua y Derechos Locales en Riesgo con la Minería a Tajo Abierto.

Haarstad, H. and Floysand, A. (2007) "Globalization and the Power of Rescaled Narratives: A Case of Opposition to Mining in Tambogrande, Peru", Political Geography 26(3): 289-308. 
Harvey, D. (1996) Justice, Nature and the Geography of Difference (Cambridge, MA: Blackwell).

Holden, W. and Jacobson, D. (2008) "Civil Society Opposition to Nonferrous Metals Mining in Guatemala", Voluntas 19: 325-350.

Jahncke Benavente, J. and Meza, R. (2010) Derecho a la Participación y a la Consulta Previa en Latinoamerica (Lima: Fedepaz Muqui Miserer CIDSE).

Kurtz, H. (2003) "Scale Frames and Counter Scale Frames: Constructing the Social Grievance of Environmental Injustice", Political Geography 22: 887-916.

Leitner, H., Seppard, E. and Sziarto, K.M. (2008) "The Spatialities of Contentious Politics", Transactions Institute of British Geographers 33: 157-172.

Marquez, N. (2009) "Más del 90\% de Pobladores de Cocachacra se pronunció en contra de la Instalación Extractiva y de la Utilización de Aguas Subterráneas", La Jornada de Arequipa Journal, http://www.jornaldearequipa.com/Tambo.htm, date accessed 10 August 2013.

McGee, B. (2008) An International Observer's Account of a Local Vote in Río Blanco Peru, Environmental Defender Law Center, http://www.edlc.org/ resources/local-votes/observers-account/, date accessed 20 January 2013.

McGee, B. (2009) "The Community Referendum: Participatory Democracy and the Right to Free, Prior and Informed Consent to Development", Berkeley Journal of International Law 27(2): 570.

Mérida, A.C. and Krenmayr, W. (2010) Sistematización de Experiencias 20082009: Tejiendo entre los Pueblos la Defensa del Territorio (Guatemala: Asamblea Departamental por la Defensa de los Recursos Naturales Renovables y no Renovables de Huehuetenango).

Movice (2012) Pueblos Indígenas y la Protección del Territorio. Cartografía de Impulsos y Restricciones de Movimiento en el Territorio, http://www. conlospiesporlatierra.net/?p=1543, date accessed 10 August 2013.

Municipal Code (2002) "Decree 12-2002: Municipal Code Congress of the Republic of Guatemala".

Municipality of Kañaris (2012) Datos Económicos y Sociales, http://www. munikanaris.gob.pe/DatosDistrito.php, date accessed 20 August 2013.

Muradian, R., Martinez-Alier, J. and Correa, H. (2003) “International Capital Versus Local Population: The Environmental Conflict of the Tambogrande Mining Project, Peru", Society and Natural Resources 16: 775-792.

National Electoral Office (2002) Resolución RJ N098-2002-J/ONPE, http:// www.web.onpe.gob.pe/modResoluciones/descargas/RJN098-2002-J.pdf, date accessed 2 March 2002.

Nisgua (2011) Comunidades rechazan Iniciativa por Normar las Consultas Comunitarias, http://nisgua.blogspot.com.es/2011/03/comunidades-rechazaniniciativa-por.html, date accessed 3 January 2014.

OCMAL (2011) Cuando tiemblan los Derechos: Extractivismo y Criminalización en América Latina (Quito: OCMAL-Acción Ecológica).

Ostrom, E. (1990) Governing the Commons: The Evolution of Institutions for Collective Action (New York: Cambridge University Press).

OXFAM (2007) Río Blanco: History of a Mismatch in Peru, Oxfam America, http://www.oxfamamerica.org/articles/rio-blanco-history-of-a-mismatch-inperu/?searchterm=majaz, date accessed 10 January 2013.

OXFAM (2009) Oxfam calls for an Investigation of Alleged Torture of 28 in Peru, http://www.oxfamamerica.org/articles/oxfam-calls-for-an-investigationof-alleged-torture-of-28-in-peru, date accessed 19 January 2013. 
Paterson, M., Humphreys, D. and Pettiford, L. (2003) "Conceptualizing Global Environmental Governance: From Interstate Regimes to Counter-Hegemonic Struggles", Global Environmental Politics 3: 1-10.

Perez Guartambel, C. (2012) Agua u Oro. Kimsakocha la Resistencia por el Agua (Cuenca: Universidad Estatal de Cuenca).

Portugal Mendoza, C. (2005) "Gobernanza en el Acceso a la Actividad Minera a los Recursos Naturales Locales: El Caso Tambogrande", Grupo de Investigaciones Económicas.

Radio Uno (2008) Este Viernes remitirán Resultados de Consulta en Candarave al Ejecutivo y al Legislativo, http://www.radiouno.pe/noticias/3963/upt_banner. swf, date accessed 10 August 2013.

Rasch, E.D. (2012) "Transformations in Citizenship: Local Resistance against Mining Projects in Huehuetenango (Guatemala)", Journal of Developing Societies 28(2): 159-184.

Red Muqui (2009) "La Consulta Vecinal: Un Mecanismo de Democracia Directa para los Pueblos", in America Latina: Riqueza Privada, Pobreza Pública (Lima: CIDSE-ALAI).

Red Muqui (2011) "Valle de Tambo-Islay. Territorio, Agua y Derechos Locales en Riesgo con la Minería a Tajo Abierto", Red Cooperacción, Frente de Defensa del Valle de Tambo, Municipalidad Distrital de Dean Valdivia Muqui.

Revenga, A. (2005) Sipakapa NO se vende. Sipakapa qal k'o pirk'ey xik, Documentary. Caracol Producciones.

SEGEPLAN (2002) Propuesta de Política para el Desarrollo Rural (Guatemala: Secretaría General de Planificación y Programación de la Presidencia SEGEPLAN).

Servindi (2012) Perú: En Consulta Communal el 95\% de Votantes de Kañaris rechazó Proyecto Minero Cañariaco, guamina.blogspot.com.es/2012/10/peruen-consulta-comunal-el-95-de.html, date accessed 10 January 2013.

Schlosberg, D. (2007) Defining Environmental Justice: Theories, Movements, and Nature (New York: Oxford University Press).

Smith, N. (1996) "Spaces of Vulnerability: The Space of Flows and the Politics of Scale", Critique of Anthropology 16: 63-77.

Subies Grau, T., Beltrán, M.J., Mérida, J.M., Moreno, M., Salas, I., Sánchez Corominas, A., Soler, M. and Parea, M. (2005) "El Éxito de Tambogrande", Ecología política 30: 95-116.

Suryanata, K. and Umemoto, K. (2005) "Beyond Environmental Impact: Articulating the 'Intangibles' in a Resource Conflict", Geoforum 36: 750-760.

Svampa, M. and Antonelli, A. (eds) (2009) Minería Transnacional, Narrativas del Desarrollo y Resistencias Sociales (Buenos Aires: Biblos).

Trentavizi, B. and Cahuec, E. (2012) "Las Consultas Comunitarias de 'Buena Fe' y las Prácticas Ancestrales Comunitarias Indígenas en Guatemala", Centro de Investigaciones Regionales de Mesoamérica - Oficina del Alto Comisionado para los Derechos Humanos de las Naciones Unidas.

UNOPS/PNUMA (2011) Revisión "ad hoc" del Estudio de Impacto Ambiental, Proyecto Tía María, Informe de Observaciones y Requerimiento de Información Complementaria, http://xa.yimg.com/kq/groups/2122051/1296039927/name/ Revisi\%C3\%B3n+del+Estudio+de+Impacto+Ambiental+del+Proyecto+ T\%C3\%ADa+Mar\%C3\%ADa.pdf, date accessed 10 January 2013.

Urkidi, L. (2011) "The Defence of Community in the Anti-Mining Movement of Guatemala", Journal of Agrarian Change 11(4): 556-580. 
Urkidi, L. and Walter, M. (2011) "Concepts of Environmental Justice in Anti-Gold Mining Movements in Latin-America", Geoforum 42: 683-695.

Van de Sandt, J. (2009) Mining Conflicts and Indigenous Peoples in Guatemala (The Hague: Cordaid - University of Amsterdam).

Walter, M. and Martinez-Alier, J. (2010) "How to Be Heard When Nobody Wants to Listen: The Esquel Mining Conflict", Canadian Journal of Development Studies 30(1-2): 281-303.

Xiloj, L. and Porras, G. (2008) Diagnóstico sobre el Derecho a la Consulta que tienen los Pueblos Indígenas y sus Consecuencias Jurídicas y Políticas a Partir del Caso de la Explotación Minera en el Departamento de San Marcos (Guatemala: Fundación Rigoberta Menchú).

Yappert, S. (2009) "Pedimos que pongan Freno a estos Proyectos de Muerte", Rio Negro Newspaper 5/5/2009.

Except where otherwise noted, this work is licensed under a Creative Commons Attribution 3.0 Unported License. To view a copy of this license, visit http://creativecommons.org/licenses/by/3.0/ 